\title{
A Summary of the Structure and Dynamics of International Trade Opportunities for New Technologies
}

September 1979

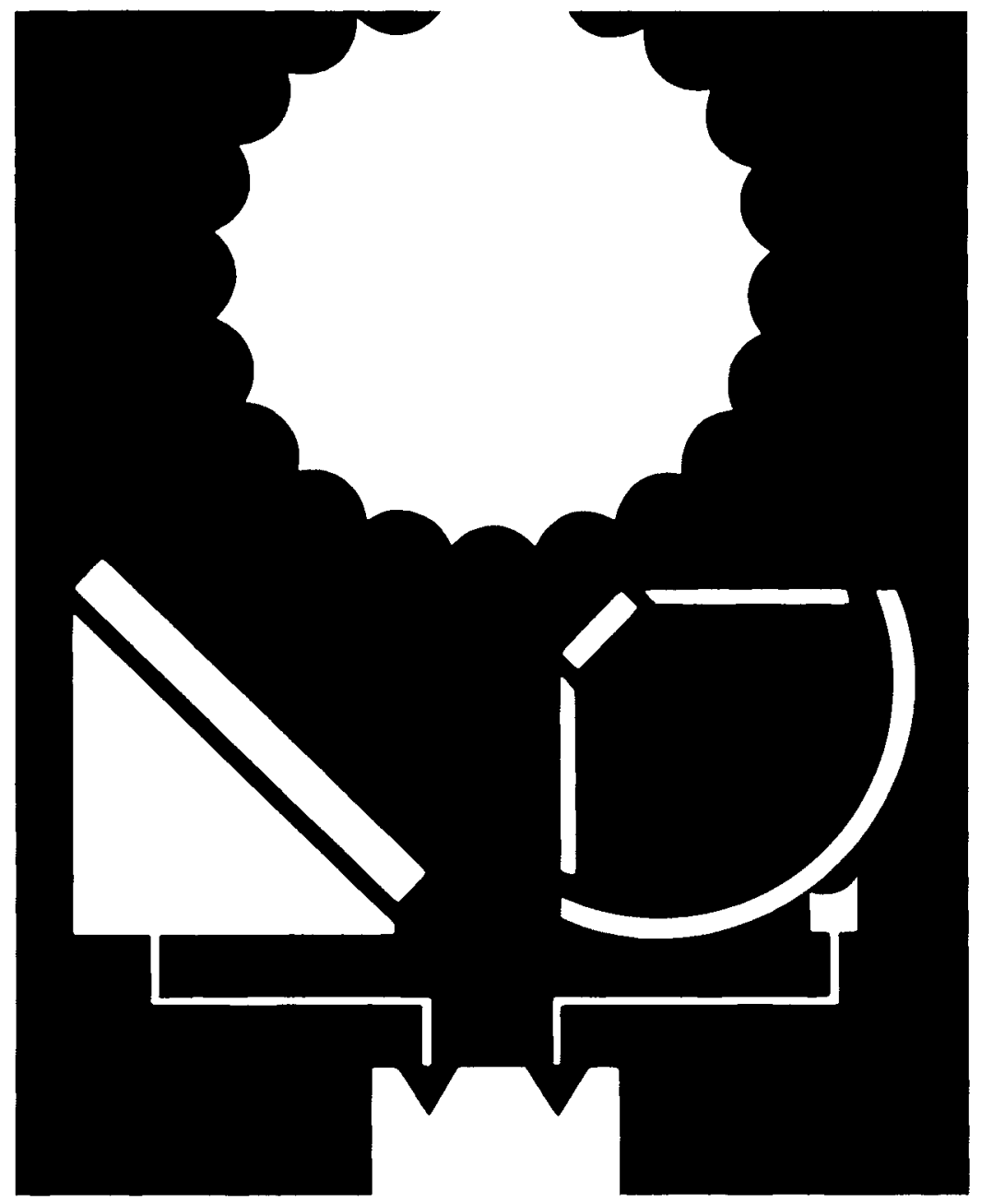

Pacific Northwest Laboratory

Operated for the U.S. Department of Energy

by Battelle Memorial Institute

\section{कै. Battelle}


NOTICE

This report was prepared as an account of work sponsored by the United States Covernment. Neither the United States nor the Department of Energy, nor any of their employees, nor any of their contractors, subcontractors, or their employees, makes any warranty, express or implied, or assumes any legal liability or responsibility for the accuracy, completeness or usefulness of any information, apparatus, product or process disclosed, or represents that its use would not infringe privately owned rights.

The views, opinions and conclusions contained in this report are those of the contractor and do not necessarily represent those of the United States Government or the United States Department of Energy.

\author{
PACIFIC NORTHWEST LABORATORY \\ operated by \\ BATTELLE \\ for the \\ UNITED STATES DEPARTMENT OF ENERGY \\ Under Contract EY-76-C-06-1830
}

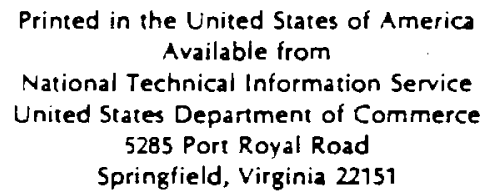

Printed in the United States of America Available from

National Technical Information Service United States Department of Commerce

5285 Port Royal Road

Springfield, Virginia 2215

Price: Printed Copys *; Microfiche $\$ 3.00$

\begin{tabular}{lr}
-Pages & \multicolumn{1}{c}{$\begin{array}{c}\text { NTIS } \\
\text { Selling Price }\end{array}$} \\
$001-025$ & $\$ 4.00$ \\
$026-050$ & $\$ 4.50$ \\
$051-075$ & $\$ 5.25$ \\
$076-100$ & $\$ 6.00$ \\
$101-125$ & $\$ 6.50$ \\
$126-150$ & $\$ 7.25$ \\
$151-175$ & $\$ 8.00$ \\
$176-200$ & $\$ 9.00$ \\
$201-225$ & $\$ 9.25$ \\
$226-250$ & $\$ 9.50$ \\
$251-275$ & $\$ 10.75$ \\
$276-300$ & $\$ 11.00$
\end{tabular}




\section{1}

A SUMMARY OF THE STRUCTURE AND DYNAMICS OF INTERNATIONAL TRADE OPPORTUNITIES

FOR NEW TECHNOLOGIES

Ray Watts

Richard Campbe 11

Steven Smith

Paul Sommers

July 1979

Prepared for

the U.S. Department of Energy under Contract EY-76-C-06-1830

Pacific Northwest Laboratory

Richland, Washington 99352 



\section{OBJECTIVE}

The objective of this paper is to 1) identify key actors and their Interactions, 2) define steps needed to accelerate the export market, 3) highlight the major differences between mature international trade patterns and early sales patterns of emerging technologies. This approach may be useful in analyzing whether and/or how the government could proceed in accelerating commercialization of emerging technologies. 


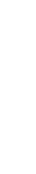




\section{STRATEGY}

The key participants or "actors" in international trade are identified. Their criteria for participation are discussed and their complex patterns of interaction are briefly explored. Preliminary conclusions and directions for future investigation result from considering these actors, their criteria for participation, and their patterns of interaction. 


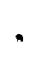

.

. 


\section{OVERVIEW}

This paper has two purposes. The first is to provide a nomenclature and symbol system for describing the "infrastructure" that supports the export (or the import) of goods between countries. While our principal interest is in the export of high technology goods to early foreign markets, the principles involved also apply to domestic commercialization of new technologies.

A nomenclature-symbol system is presented providing a schematic method of displaying complete relationships between actors and functions - an interaction matrix. The structure of the matrix, i.e., the order of the rows and columns and the conventions we have adopted have suggested both empirical hypotheses and policy options. This implies that further work would be useful both for theoretical and applied purposes.

A second aspect of the paper involves sketching out the need for further work to identify the motives, problems, and constraints of each key actor in international trade, particulariy regarding new high technology products. We believe that the investigation should emphasize initial phases of market development when the behavior of actors does not appear to follow previous applications of microeconomic theory. Understanding this difference between theory and behavior could improve federal efforts to commercialize new technologies. 


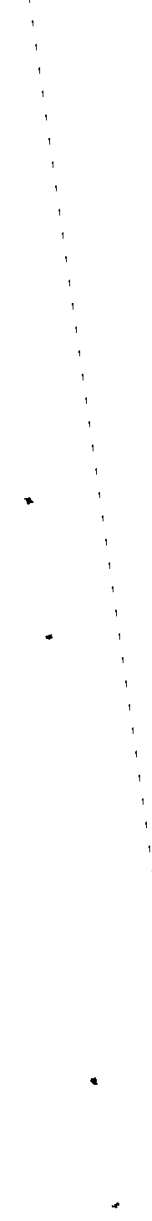


CONTENTS

OBJECTIVE

STRATEGY

OVERVIEW

vi i

TABLES

FIGURES

1.0 INTRODUCTION

1.1

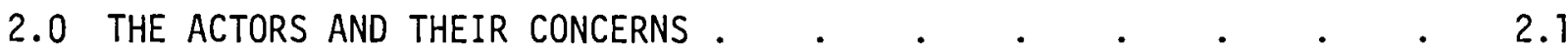

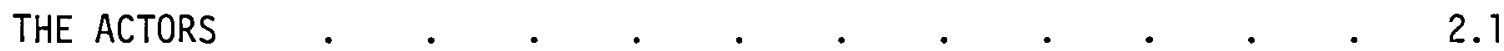

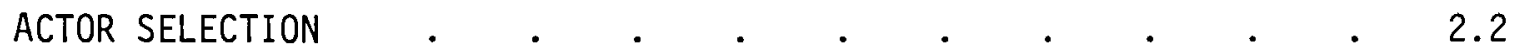

ACTORS' PARTICIPATION IN COMMERCIALIZATION $\quad . \quad \ldots \quad . \quad . \quad . \quad 2.3$

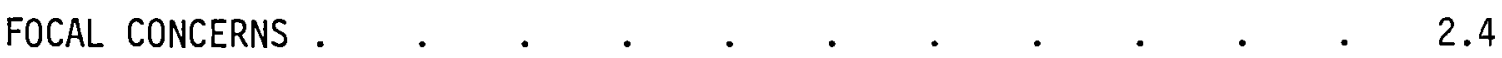

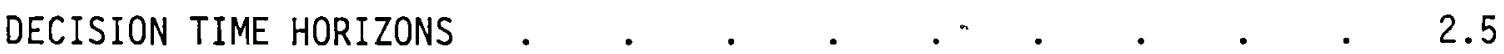

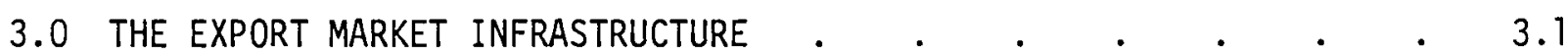

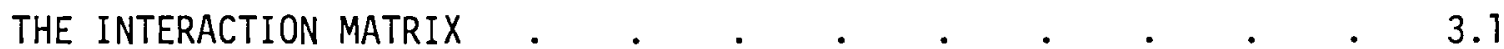

4.0 SUCCESSFUL MARKET PATTERNS $\quad . \quad$.

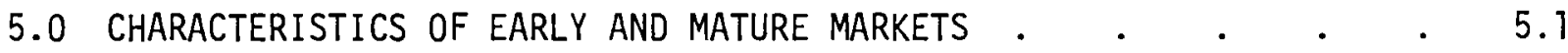

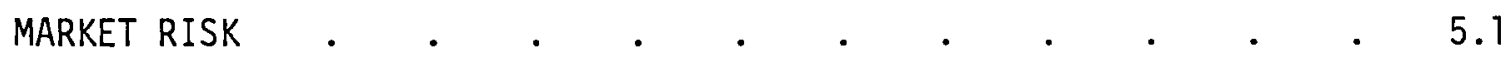

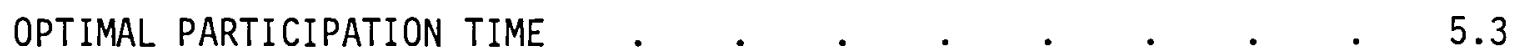

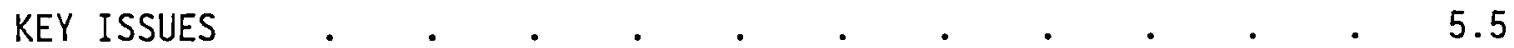

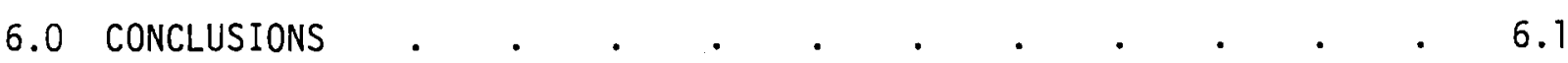

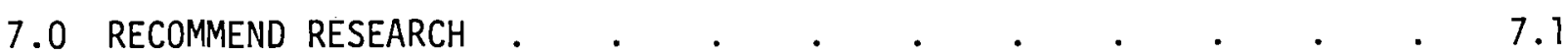

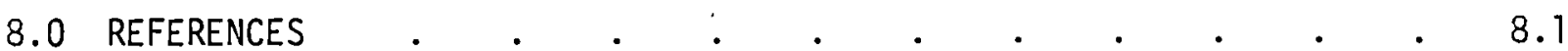


$\underline{\text { TABLES }}$

2.1 Actors Involved in International Trade . $. \quad . \quad . \quad . \quad$. 2.1

\section{FIGURES}

3.1 An Interaction Matrix Showing an Example Transaction Where a Manufacturer Ships Directly to a Buyer Who Pays Cash . . . 3.2

3.2 An Example Interaction Matrix Showing Some of the Transactions Occurring in a Mature Export Market . . . . . . . 3.3

3.3 A Japanese "de facto" System Displayed on the Interaction Matrix . 3.5

4.1 One of a Kind on Large Sales Characteristic Illustrated in

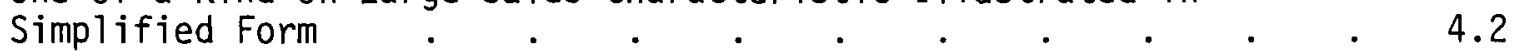

4.2 An Interaction Matrix Displaying the "de facto" I. M. Singer Organization 100 Years Ago . . . . . . . . . . 4.3

4.3 Interaction Matrix Displaying 01d and Newer Patterns of Sears and Roebuck Co. Operation . . . . . . . . . . . 4.4

4.4 Government R\&D Project . . . . . . . . . . . . . 4.5

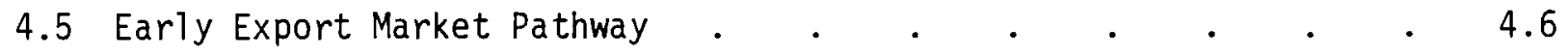

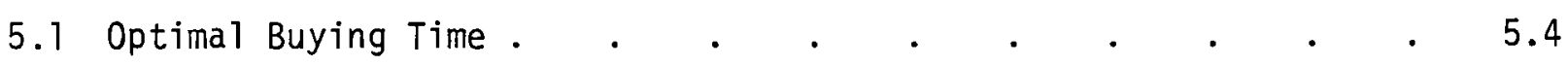




\subsection{INTRODUCTION}

The current widespread interest in potential export markets for U.S. products stems from several concerns. Some of these concerns are: a need for a broader market to produce economies of scale; the need to create new jobs for American workers; and a recognition that exports can favorably affect our balance of trade.

The United States is entering a new economic phase in which its leadership in technological areas is less certain than in the past. The United States faces rapidly stiffening competition in the international markets. The competition for resources to supply our industry is growing more intense. This is also true in the market for our products. Increasing competition results in higher prices for commodities we purchase and lower receipts for products we sell. Maintaining a favorable balance of trade and a strong dollar is becoming a greater problem.

The future commercial potential of emerging U.S. technologies in international trade will depend on several things:

- Technical Performance -- How well does it work?

- Economic Performance -- How much does it cost?

- Competitive Performance -- How do our technical and marketing efforts compare with those of other nations?

In turn, these factors are influenced in the natural course of things by what are generically called "barriers" and "incentives". In a perfect laissezfaire free market there are no barriers or incentives beyond those flowing from strictly economic forces. However, since the late 1800 s, energy has been sufficiently crucial to warrant domestic political and economic policies intended to increase its production and consumption. Cone, et al. (1976, 1979) have noted that more than $\$ 200$ billion in economic incentives have been spent on conventional energy sources since 1918. There can be little doubt that an indirect effect of these incentives has been to encourage the export of some products to other countries, e.g., nuclear reactors, petroleum refineries, and well drilling equipment. 
Of major concern in exporting new technologies is the kind and size of role the Federal government takes. This paper necessarily discusses aspects of this question. In earlier, more innocent times one might have phrased it differentiy. Perhaps, "Should the Federal government be involved in . . . ?" For better or worse the Federal government is a major actor in export commercialization -- a situation unlikely to change in the foreseeable future.

Export markets for emerging technologies are at present poorly understood. There is no adequate methodology for dealing with the uncertainties of R\&D, the results of competition with existing products, cost reduction opportunities in mass production and potential competition with others who are also interested in the same markets.

For a number of reasons, including the determination of foreign competitors, who are smarting under the U.S.' continued domination of markets for electronic computers, aircraft, etc., we see small emerging high-technology firms as having potentially serious difficulties in exporting their products. This situation exists because the U.S. lacks an infrastructure abroad to handle the business.

In attempting to understand the dual dynamics of commercializing new technologies and simultaneously exporting them, we have found it necessary and useful to conceptualize what might be called a "theory of international commercialization", which draws upon numerous historical examples to formulate some strategic principles.

Let us first make the observation that export commercialization condenses down to making a connection between a buyer and a manufacturer of a technology. In the long run, of course, this connection is an exchange, and in a purely private enterprise world this connection tends to be determined by strictly economic considerations. Under normal circumstances the buyer and the seller are sufficiently motivated and endowed with resources and information that they will get together. Unfortunately, due to externatities and other market imperfections, many socialiy worthwhile export markets may not be developed by the private sector. The government may be able to help get these markets established by performing various roles in the early stages of R\&D and commercialization. Eventualiy, conditions for a viable private sector market may be created in this manner. 
Even in a normal situation the buyer and the seller are not the only actors involved. In the world outside of text books there are a host of other actors who may have critical roles to play at one point or another in the process. The roles of these additional actors must be fully understood. This paper outlines the actors in international trade, the stage on which they perform, the characteristics of early and mature markets, the patterns of successful marketing efforts, and finally it examines some of the strategies for holding or increasing the U.S. share of emerging markets. 
$\checkmark$ 


\subsection{THE ACTORS AND THEIR CONCERNS}

There are many interested parties in addition to sellers and buyers directly or indirectly involved in market transactions. The interests of other parties are represented by a host of regulations, laws, permits, zoning rules, etc. In addition, the market itself is a complex entity with many specialized firms performing various roles. This analysis focuses on the actors, their arena, and their actions and opportunities for choice. The selection of actors for this list was done on the basis of organizational entities having distinct functions and making decisions relating to the export pathway.

\section{THE ACTORS}

In international markets the actors who approve, finance, or actually carry out the transaction typically include society, government, etc. as shown in Table 2.1 .

TABLE 2.1. Actors Involved in International Trade

- Supplier's society

- Government

- R\&D Organizations

- Capital Suppliers
- Manufacturers

- Systems Houses/ Brokers

- Local Distributors

- Installers
- Financiers

- Buyers/Users

- Buyers' Governments

- User's Society

The actors 1 isted in Table 2.1 represent classes of parties involved in international trade. For example, society represents a whole group of interests that express the balance of their relative power in the election of government. The government, in turn, taxes the constituency and funds R\&D and various incentives supporting the common good. In addition, the government passes laws and establishes regulation of the production processes and of the export business. 
For instance, the role of government goes beyond the passive role of issuing permits, etc. and now extends into financing and other more active roles. An example of this active role is found in an article from the Wall Street Journal of July 3, 1979, under the heading, "South Korea Is Said To Be About To Place U.S. Reactor Orders":

"Korea plans to borrow about $\$ 1.4$ billion from the U.S. export-import bank to help finance the projects, ..."

And later, in the same article:

"The report came two days after U.S. Treasury Secretary Michael Blumentha1, while accompanying President Carter last weekend, had asked Seoul to buy the two nuclear reactors from the U.S."

This intervention in the market process was made necessary by the international trade climate in which other governments traditionally intervene as indicated in the same article. This complexity is being dealt with effectively by ongoing businesses, but it poses special problems for emerging businesses.

\section{ACTOR SELECTION}

Those actors listed in Table 2.1 can either make, facilitate, approve or finance transactions or in some cases, prevent the transaction. They are thus directly or. indirectly "in on the deal". Other parallel transactions are omitted to simplify the discussion. For example, the various transport linkages were omitted since they do not usually decide whether a specific export business will be served.

The purpose of this study is to explore strategies for encouraging the establishment of mature export businesses from infant businesses. Therefore, we explore the relationships between the actors and the benefits and risks of their involvement in this process.

The technology diffusion (Rogers 1962) 1iterature indicates that there is a distinct difference between pioneers and the participants in a mature market. The pioneer operates in a higher risk climate and expects to capture greater return on his investment. In order to get to the mature market we need to go through the stage where pioneering is required. A variety of designs, markets 
and commercialization pathways will be tried out if a large number of pioneers are allowed to participate. Early designation of a particular design, market or pathway may eliminate this opportunity for the market to evaluate alternative approaches. It is important that the conditions which nurture the beginning market (pioneering) are not destroyed.

The actors listed in Table 2.1 may not all be involved in a given transaction but most, if not all, functions implied will be represented or severe problems are likely to be encountered.

The classes of actors shown in Table 2.1 are surprisingly complex -- for instance, the government class includes city, county, state, and federal agencies. Federal agencies include the Department of State, Department of Commerce, Department of Energy, and other agencies such as the Agency for International Development, Small Business Administration, Internal Revenue Service, the U.S. Information Agency and others.

The market complexity is a major barrier to starting export businesses. It is remarkable that the various actors overcome this complexity to fill out a 11 the forms, get a 11 the permits and contact all of the interested parties. In specific instances some of the parties and/or functions are bypassed, but the mature profitable market includes most of them and we are concerned with accelerating the emergence of a mature profitable market pattern.

We next explore the factors necessary for participation in this market. We argue here that we can explain the emergence of this mature market by understanding the focal concerns of the participants.

\section{ACTORS' PARTICIPATION IN COMMERCIALIZATION}

An actor will consider participating in the commercialization of an emerging technology if the perceived benefits from participation are greater than the perceived costs over the actor's time horizon. If the perceived costs are greater than the benefits, the actor will not consider this commercialization venture.

The mere fact that the benefits appear to exceed the costs does not mean that the actor will actually select the specific commercialization opportunity. He will select among alternatives and there are many reasons why he may not 
select a given alternative. There may be instances in the short run where an actor will participate, yet his perceived costs exceed his perceived benefits. This situation is likely to be either transient and/or may be an indication that the actor is not really needed in the long run.

It is important to identify the costs and benefits accruing to each actor from participation if a strategy is going to be formulated to encourage participation in the export market. This can be accomplished by examining each actor's focal concerns.

\section{FOCAL CONCERNS}

We can understand, predict, and influence the various actors involved in commercialization if we understand what we shall term "focal concerns", a phrase borrowed from sociology to describe subcultures. (a) Here, focal concerns are defined as a set of influences that an actor habitually considers at least unconsciously before acting. These concerns tend to be common to similar actors. That is, marketing managers tend to be concerned with the similar problems regardless of the type of company, i.e., pleasing their bosses and moving ahead in their career. Similarly, potential buyers of new products tend to be faced with similar doubts and reservations. It is this commonality among actors which lies close to the heart of understanding of the how, why or why not of commercialization (see Table 2.1).

There is no single community of interests within an actor category. For example, there are important differences in focal concerns of each actor within the following categories of a manufacturing company:

- Operating Officers

- Executive Directors

- Institutional Investors such as Stock and Bond Holders

- Other Investors

(a) Note: The focal concerns methodology is similar to behavioral thories of the firm, in which firm managers are assumed to value growth, sales, or a quiet life in addition to profits (Cohen 1975). 
These focal concerns help explain an actor's desire to participate in the commercialization process by providing clues to his perceived benefits and costs. A very important local concern to consider is each actor's decision time horizon.

\section{DECISION TIME HORIZONS}

Conventional economic wisdom teaches that investments are made on the basis of expected rate of return and that higher risk investments command higher interest rates. It is also well known that the time preference for returns now, compared to returns later, can be represented by discount rates.

However, in the real world individuals often make decisions as if there is no tomorrow", that is to say, the time horizon beyond which one cannot see depends on the situation -- and for many it is astonishingly short.

Some examples are:

- General managers in industry are either successful and "moved up" or are unsuccessful and are fired within 1 to 4 years;

- Homeowners in the upper middle class move an average of every 2 to 5 years;

- Politicians term of office lasts 2 to 4 years; and

- Many export businesses operate on cash or short term credit. Profits must be realized within weeks or months.

For these real human actors, their focal concerns are not necessarily centered on life cycle cost, ultimate payback time or overall lifetime return on investment. Their concern may be shorter in range and more concrete: "Will this pay off before the next election, board meeting, budget review, etc.?" or, "Am I going to be responsible if this fails for longer than I will get credit if it succeeds?"

Decision makers in the real world then do not use purely accounting-type figures of merit in making decisions. Personal and organizational concerns are both part of the process in varying proportions, particulariy during the initial growth phases of a business or product line.

In summary, formal analyses aside, all the actors involved are human beings who have egos, catch colds, get hired, promoted or fired and worry about their 
own interests as well as the organizations in which or through which they act. Failure to recognize the psychological and social forces at work is to miss both the major impediments and the strongest driving forces behind the adaption of new innovations. 


\subsection{THE EXPORT MARKET INFRASTRUCTURE}

The success of a product depends on how the actors in the marketplace perceive and relate to each other and the actions they consequently take as well as how they perceive the product.

In this section we discuss the arena or stage where the actions take place and indicate some barriers that are built into the situation. We also indicate some important conditions for success.

In this report we use a flexible "interaction matrix" representation which can accommodate the wide variety of relationships encountered both in new and in mature markets, and can also conveniently portray the ACTIONS (including intangible exchanges) that dramatically affect ultimate outcomes in the marketplace.

\section{THE INTERACTION MATRIX}

An example interaction matrix representation of the market arena is shown in Figure 3.1 where the rows and columns represent initiators and receivers of the actions, respectively. On this figure we illustrate a highly simplified transaction where a manufacturer ships directly to a user who makes the purchases with cash. Actual exports tend to be much more complex; permits are required to export and import and irrevocable letters of credit or other complications may be involved.

The actual situation in a mature market can be extremely complex. Actions taken by actors in this representation include: the generation of goods, the supplying of funds, the issuance of permits, and the generation of jobs, etc.

In other words, the actions include the whole range of tangible and intangible goods, services and actions regarded by receivers as having value. 


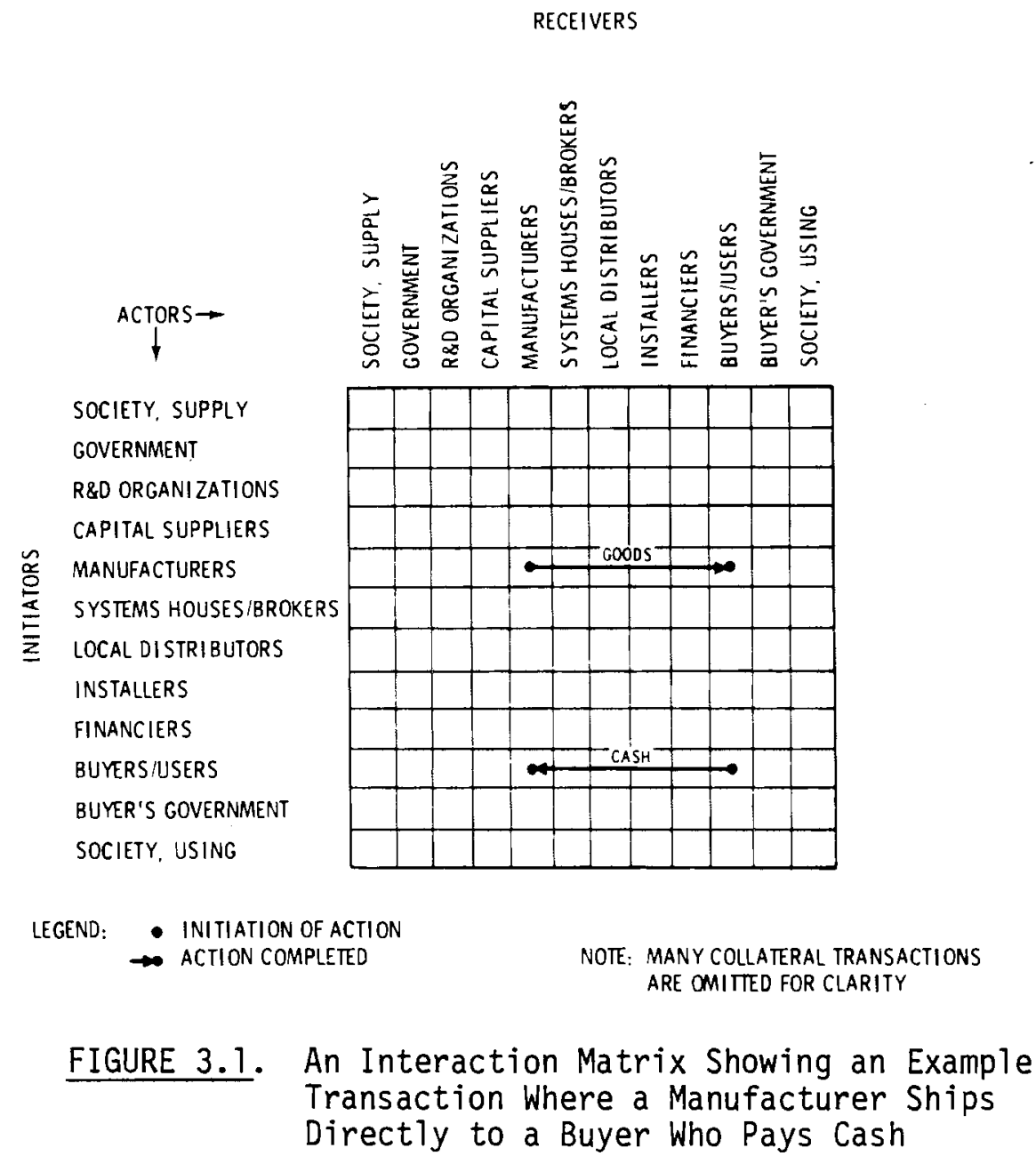

We have illustrated some of the complex actions in a mature market in Figure 3.2 .

The conventions of this interaction matrix representation of the market arena can be summarized as follows:

- Actions originate on the diagonal and move down the diagonal for vertically integrated systems;

- Arrows moving horizontally from the diagonal to a column represent a transaction originating with a large $\operatorname{dot}(\bullet)$ and ending in the column of the receiving organization with the head of the arrow; 
RECEIVERS
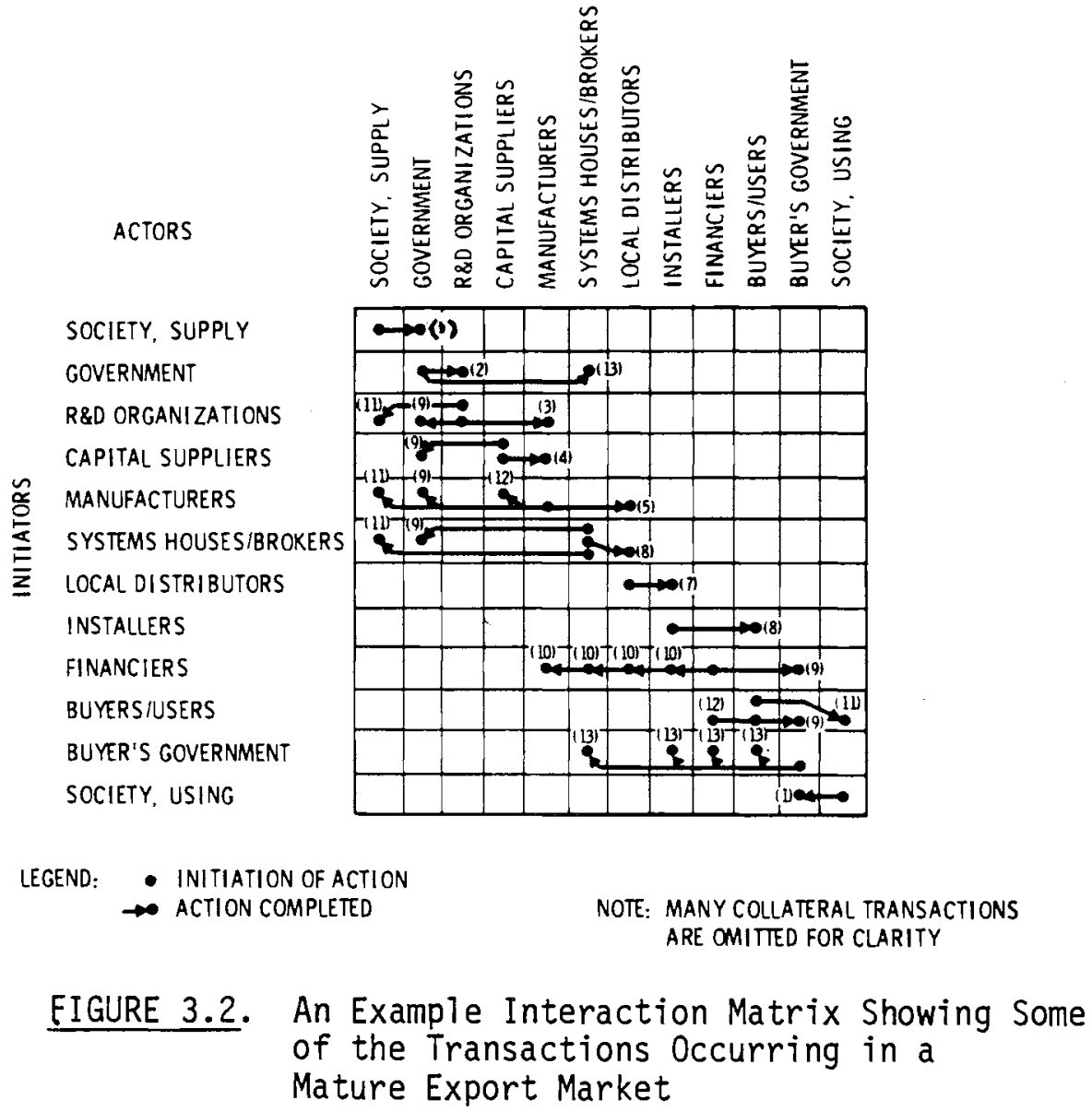

\section{TRANSACTIONS}

1. Constituency and taxes supplied

2. Projects funded

3. New concepts supplied

4. Capital (equity and working) supplied

5. Components, parts, etc.

6. Systems, parts, etc.

7. Systems, parts, and local materials

8. Working system

9. Taxes

10. Installed price

11. Jobs and improved living conditions

12. Payments and interest

13. Permits and licenses and zoning, etc. 
- An elongated circle indicates the extent of a vertically integrated organization by enclosing large dots on the diagonal, as follows:

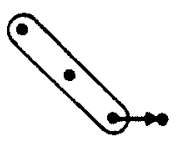

- Lines with dots on both ends are identities. (An example would be a manufacturer who uses his own product.)

- Multiple lines from a diagonal element represent multiple, i.e., parallel, paths of actions.

Next we show an example of how a vertically integrated market appears on this matrix display. A "de facto" Japanese trading company is shown with a large dot for each function supplied and an enclosing line to show its extent. The implication of this example (see Figure 3.3) is that there is a whole series of functions carried out by one team. Some of these functions are (a) government supports the trading company in many ways including R\&D funding, (b) the consortia supplies manufacturers with capital for expansion and operations of the businesses, and (c) the trading company carries inventory, spreads risk, arranges all the necessary paperwork for export and distributes and installs the product in the customer country, carries the credit for the transaction, if needed and, finally services and warranties the product.

In the previous section we indicated that there are a number of barriers involving the perceptions of various individuals selling, buying, financing and approving the transactions. In other words, the individual decision makers must see benefits exceeding costs within their time horizon.

In the longer term and for the mature markets, we submit that the sum of the perceived benefits (suitably discounted) for all players must exceed the costs (discounted) or the market is a transient situation and will not last.

In planning export markets we need to keep in mind that our product needs to be "good for the receiving society" as well as profitable for the individual actors.

At this point, we have defined a set of actors and a qualitative method of describing economic and noneconomic relations between them. We now move to 
RECEIVERS
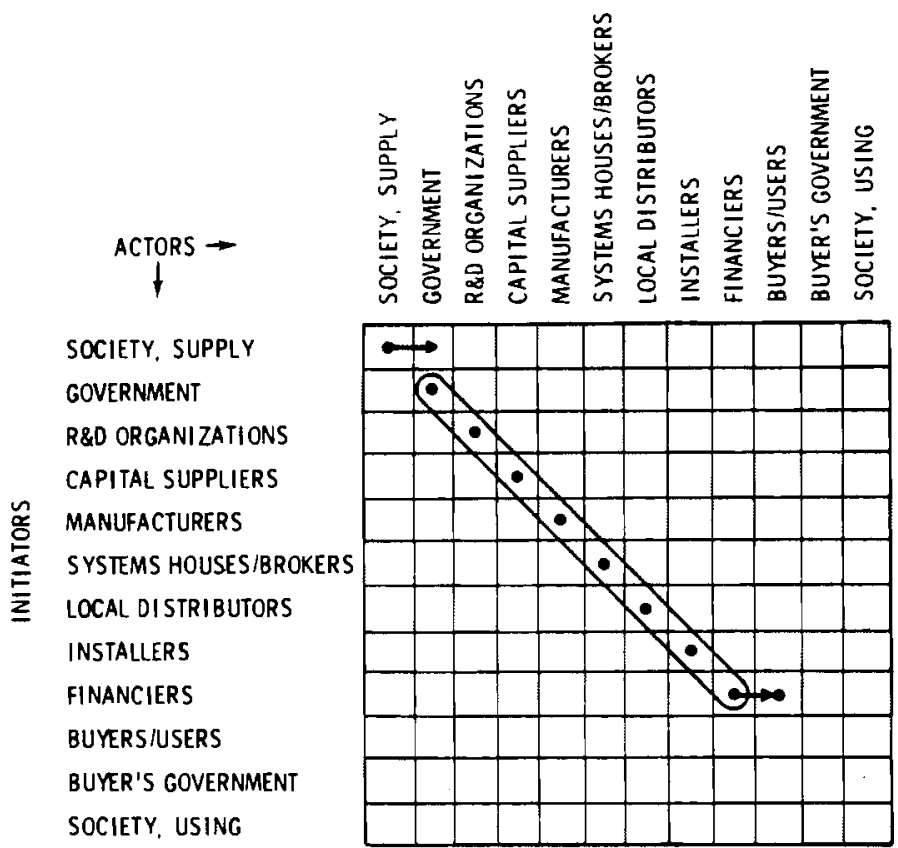

LEGEND: - INITIATION OF ACTION

$\rightarrow$ ACTION COMPLETED

NOTE: MANY COLLATERAL TRANSACTIONS ARE OMITTED FOR CLARITY

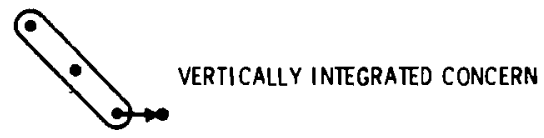

FIGURE 3.3. A Japanese "de facto" System Displayed on the Interaction Matrix

posing some more important questions about how these actors operate and, in turn, how various incentives and disincentives tend to modify their behavior. These questions are actualiy posed here in the stronger form of assertions to be discussed, challenged and tested.

The first and most important assertion is that commercialization, innovation, industrialization, technology transfer, etc. all deal with transitory, dynamic, non-steady state cases.

The literature on the firm or the organization's literature that normally might be expected to cover this system-in-flux issue is inadequate for dealing 
with the non-steady state non-equilibrium case. The predilection for dealing with a steady state problem is strong. What is done in a discounted cash flow analysis is to transform a changing future situation into a more or less stable equivalent static present situation.

We state without proof that in this transient situation actors' behavior is not well explained by the usual steady-state calculations. 


\subsection{SUCCESSFUL MARKET PATTERNS}

No single successful pattern can be followed that will guarantee success in international commercialization. There are, however, a number of outstanding success stories which can be examined using the methods of this study to identify common threads.

Obviously, one would not expect modern weapons systems to use a "K-Mart" type of merchandizing, although some might find the idea intriguing (Figure 4.1). It is likely that some new technologies will require different merchandizing patterns than other new technologies, so we look for common threads of success in a complex market situation.

According to Peter Lyon's account, Isaac Singer (Lyon 1958) became interested in sewing machines about 1850, having previously been interested in other mechanical inventions, the theater and women. Isaac singer invented a sewing machine that worked. (Previous designs did not work at all well.) Most inventors fail to capture much in the way of profits from their developments, but Singer was fortunate enough to get a man, Edward Clark, into the fledgling company.

Singer solved the mechanical problems and further developed the machine while Clark solved brilliantly the problems of competition and "international commercialization". By 1901 the Singer Company was selling more than one million machines per year and more than half was coming from international sales. These machines were selling from Archangel to China and everywhere in between.

This company broke new ground in many ways. The Singer Company estab1 ished an efficient distribution and marketing organization. "Clark established a fully developed system of franchised agencies, each of which was staffed by an agent who was also the salesman, a young woman to demonstrate the machine, a competent mechanic to service and repair the machines sold". (Lyon 1958) Further innovations included time payment plans and reduced prices to potential community trend setters such as clergymen, and generous trade-in allowances on 
RECEIVERS
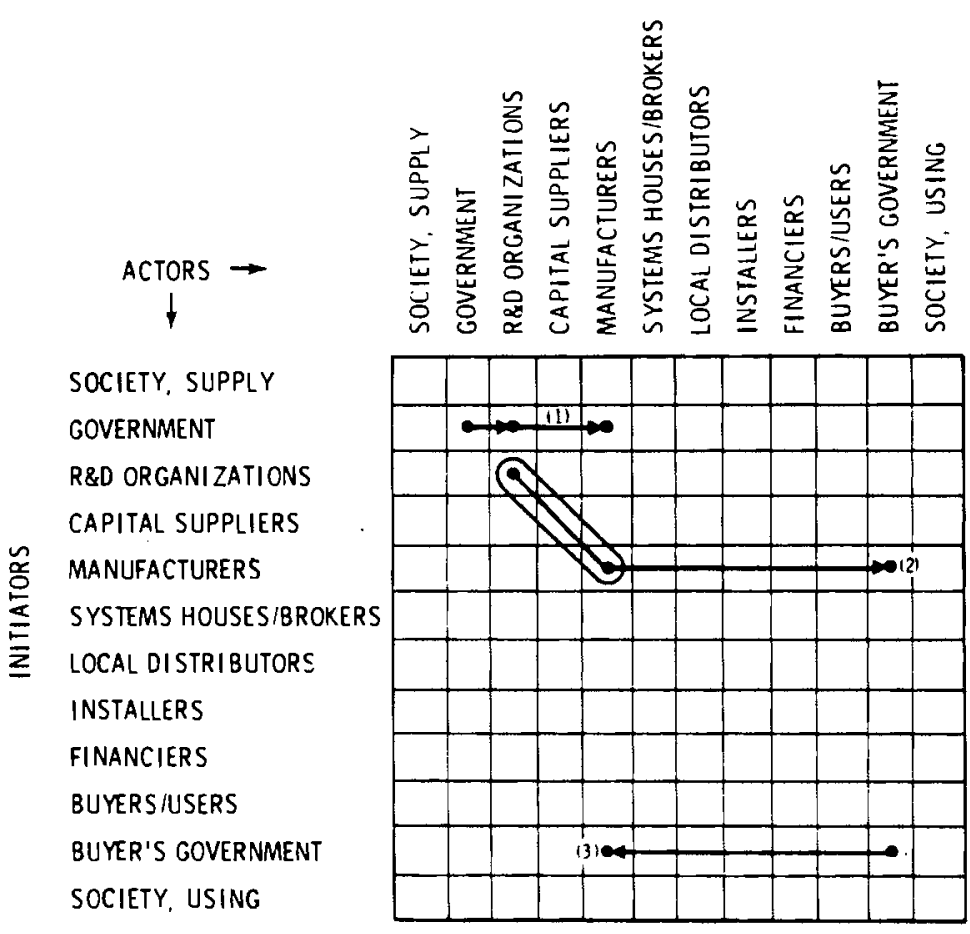

$$
\begin{array}{cl}
\text { LEGEND: } & - \text { INITIATION OF ACTION } \\
& \rightarrow \text { ACTION COMPLETED }
\end{array}
$$

NOTE: MANY COLLATERAL TRANSACTIONS ARE OMITTED FOR CLARITY

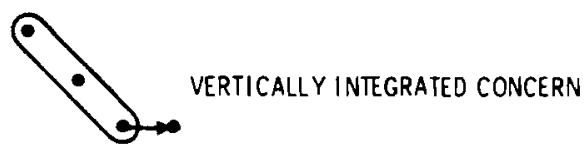

FIGURE 4.1. One of a Kind or Large Sales Characteristic Illustrated in Simplified Form

\section{LEGEND}

1. Permits

2. Weapons systems shipped

3. Payment made 
new improved models. On an interaction matrix the de facto organization looked as in Figure 4.2. Looking down the diagonal, what Clark did was to set up a management, distribution, advertizing and financing system.

RECÉIVERS

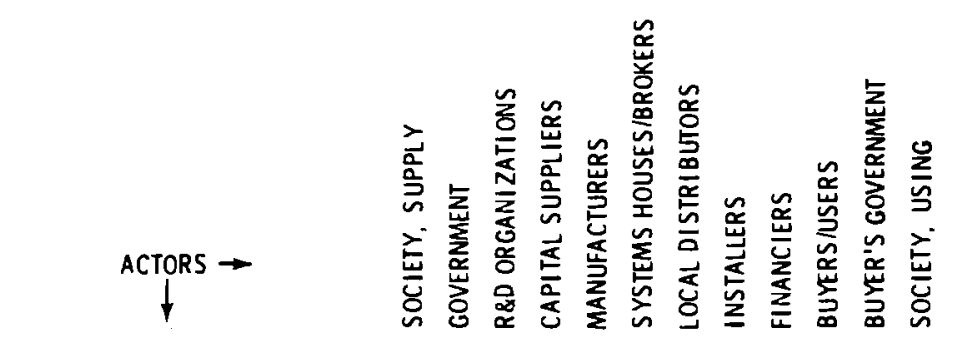

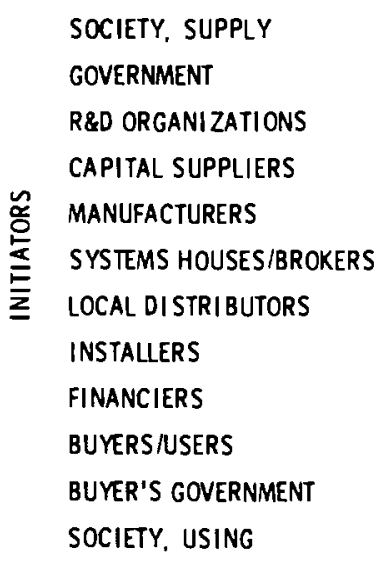

LEGEND: - INITIATION OF ACTION $\rightarrow$ ACTION COMPLETED

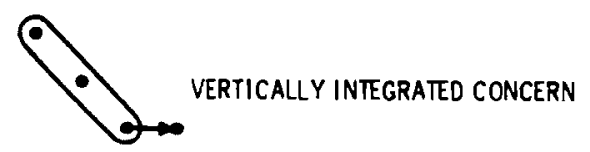

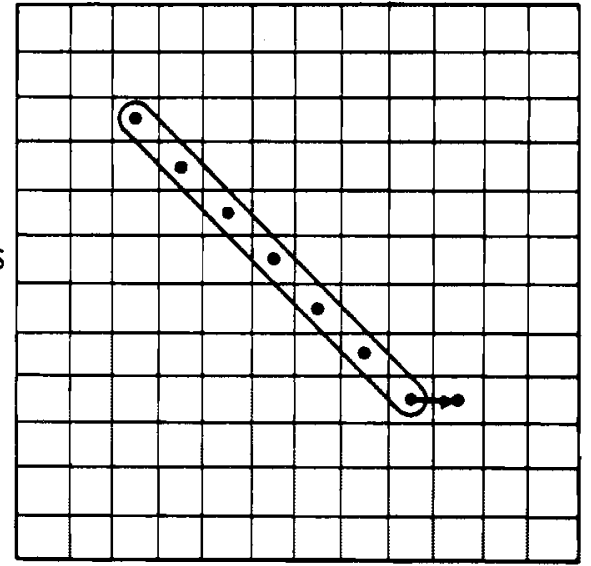

NOTE: MANY COLLATERAL TRANSACTIONS ARE OMITTED FOR CLARITY

FIGURE 4.2. An Interaction Matrix Displaying the "de facto"

I. M. Singer Organization 100 Years Ago

Another success story is that of Sears, Roebuck and Co. This company illustrates another market pattern. Initially the fame of Sears and Roebuck Co. rested on mail order business but as the nature of business changed they have adapted to the time and now an enormous chain of retail stores suppiements their mail order business. Sears has moved into international markets successfully with their marketing concepts and while they originally concentrated on 
retail sales, they are now involved in much more of the market arena. This is shown in Figure 4.3; they vertically integrate some market functions to include $R \& D$ and manufacturing.
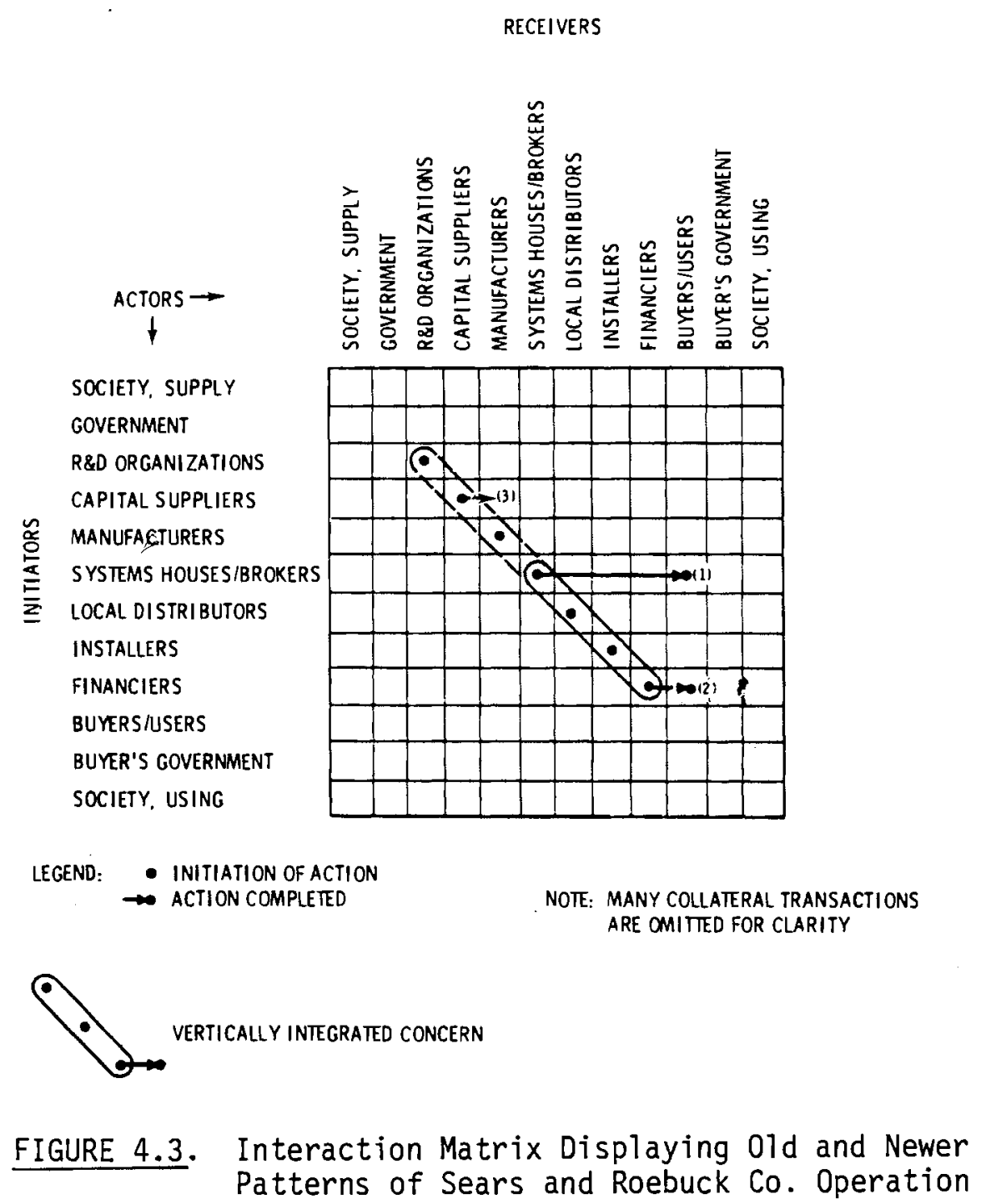

\section{LEGEND}

1. Original mail order concept

2. Modern distribution and retail outlets have been added

3. -- Dotted lines indicate that Sears now is involved in manufacturing, financing, and researching some of their products. 
The interaction matrix methodology shows the infrastructure which needs to be activated to commercialize government developed technologies. Figure 4.4 depicts the functions performed by a government agency or its contractors in a typical demonstration market. The agency performs R\&D to develop a product. It then assembles balance-of-system components to create a complete working system to meet some functional need of the user. The complete system is then installed at the user's site and put into operation. The uses may contribute part or none of the projects' costs depending on the circumstances.

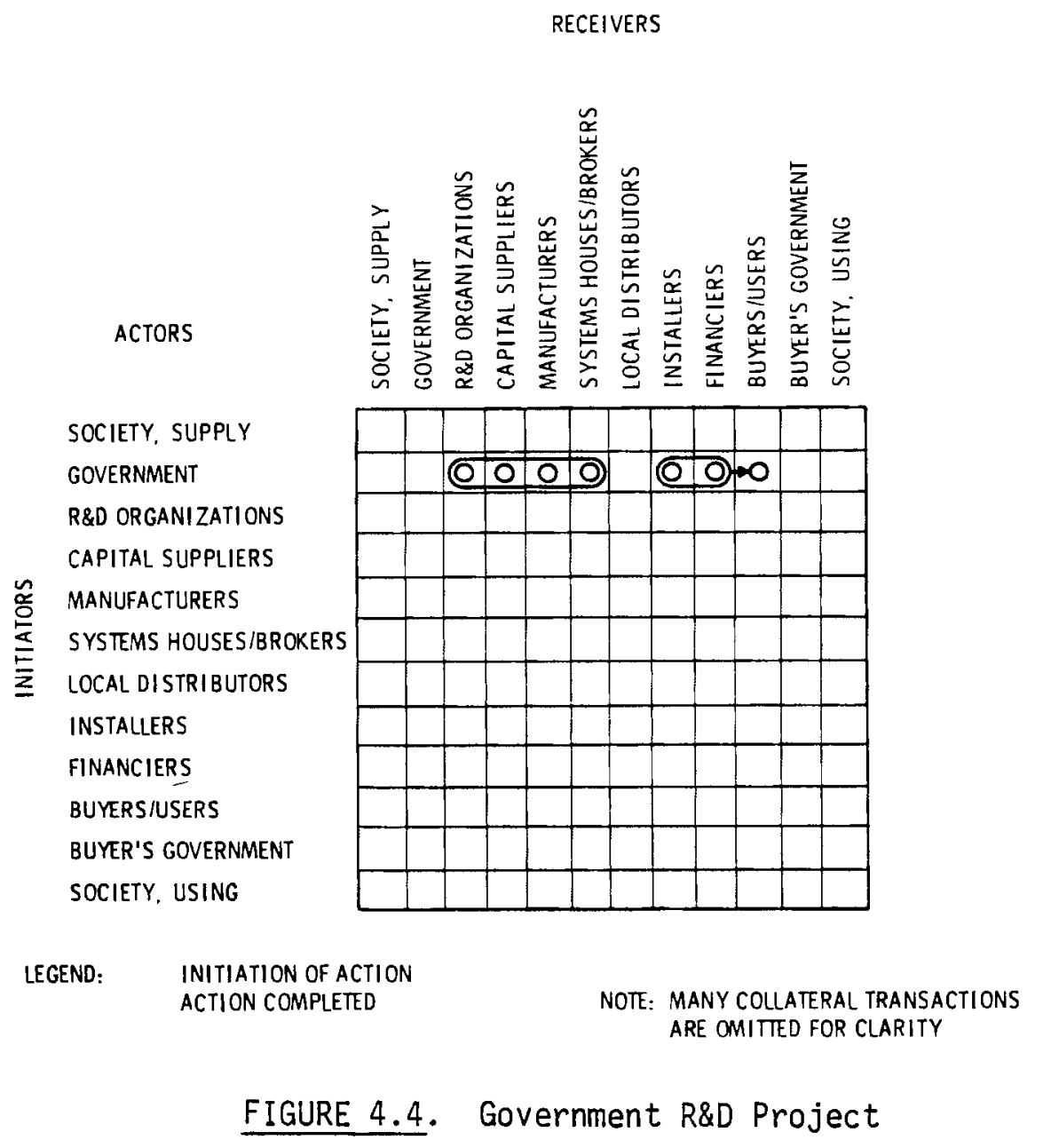


Many additional actors must be involved in a commercial transaction involving the same functional system. Alternative market pathways may be used in a commercial transaction. Figure 4.5 shows one possible market model, based on the electronic's industry model. R\&D organizations typically develop a product and begin to manufacture it on a commercial scale or sell manufacturing rights to an established manufacturing firm. This firm's products are then sold to systems houses who assemble complete functional systems from several firm's components. These systems houses sell the functional systems to distributors, who in turn sell to installers or users. Cash flows in the reverse direction, completing the transactions. In an export market several additional actors are involved, including exporting firms, customs agencies, and major transportation functions.

RECEIVERS

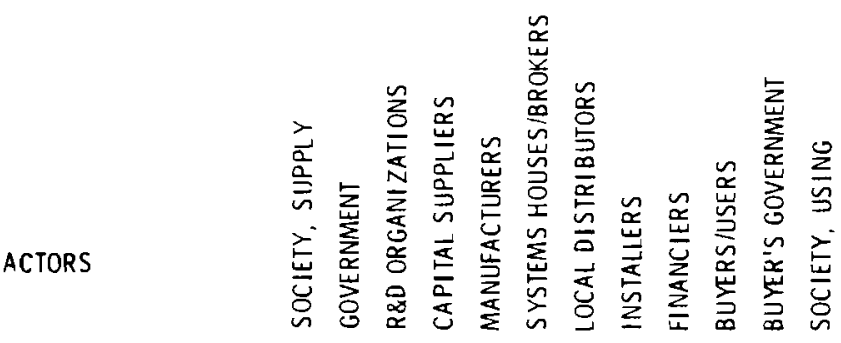

SOCIETY, SUPPLY GOVERNMENT R\&D ORGANIZATIONS CAPITAL SUPPLIERS MANUFACTURERS SYSTEMS HOUSES/8ROKERS LOCAL DISTRIBUTORS INSTALLERS FINANCIERS BUYERSIUSERS BUYER'S GOVERNMENT SOCIETY, USING

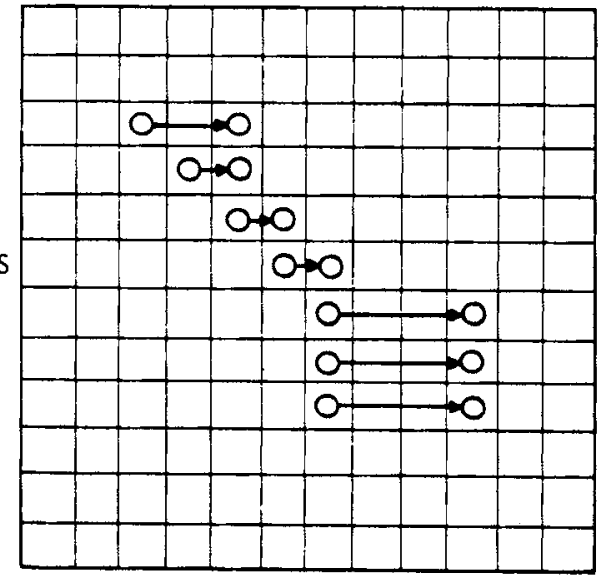

LEGEND: INITIATION OF ACTION ACTION COMPLETED

NOTE: MANY COLLATERAL TRANSACTIONS ARE OMITIED FOR CLARITY

FIGURE 4.5. Early Export Market Pathway 
In order to export a new technology such as, a complete commercial export chain such as that described above must be activated or created. A government demonstration project is far removed from a commercial market pathway. In order to evaluate the prospects for exporting solar equipment the concerns and constraints on each of the actors in the commercial export pathway must be understood. Many good ideas which seem to meet some economic need fail to be commercialized because of roadblocks encountered somewhere along these pathways. 


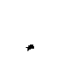

. 


\subsection{CHARACTERISTICS OF EARLY AND MATURE MARKETS}

Achieving a mature, viable market is a "Catch-22" process. In other words, you need a volume market to get the costs down and work the bugs out of a new product. On the other hand, the mainstream buyer of products does not purchase until a reliable product is available from an established dealer (Rogers 1962) indicates that pioneers, or "innovators" exist who will accept risks quite unacceptable to the market "majority".

\section{MARKET RISK}

The process of building from an idea to a mature, viable market (commercialization) is filled with risk.

There is no way to avoid this risk. Large companies with excellent marketing staffs, brilliant product planners, excellent distribution and sales promotion programs still fail spectacularly. Similarly, government efforts at commercialization can also fail. Terleckyj says, in the National Industrial Conference Board publication, Research and Development: Its growth and composition (TerleckyJ 1963) ". . . The product of research activity is not known with any reasonable degree of certainty in advance. . . In this respect, research shares certain features with lotteries, gambling and insurance." "We submit that this is true for the entire commercialization path - witness the Edsel. Nelson and Winter (1977) support this point, noting that the entire technological diffusion process is charactarized by fundamental uncertainty about technological and economic issues.

Everyone risks more in the early market than in a mature market. For example, society may find unexpected hazards associated with the manufacture or use of a product. Government may get voted out of or into office as a result of an activist movement against a new product or process (e.g., nuclear reactors in Sweden). R\&D organizations and manufacturers can go out of business if they guess wrong. 
Fortunately, there may exist pioneers in each actor class. These pioneers bet their future, their cash, and sometimes, as it were, their health and their life on a new concept. They bet on their unique knowledge and abilities -that they can do what others could not do.

We state without proof that progress will be absent if societies, governments and entrepreneurs lose the ability or the will to take risks.

Early markets have greater opportunities for greater profits and for gaining market position providing considerable incentives are available for early participants. The first and most important incentive to innovation is, of course, a larger than usual economic profit, which, in principle, is supposed to flow to the early participants. The man with the better mousetrap and those who beat a path to his door are supposed to capture disproportionate economic benefits in relation to those who come later. This mythical conception of the flow of rewards, however, is generally wrong. The typical new "mousetrap" is neither significantly better, nor does it generate the sound of beating feet. The objective statistics regarding new inventions, new firms and new products are notoriously grim: roughly one invention in a thousand makes it past any serious screening. Roughly $95 \%$ of new firms fail in the first year. Roughly $40 \%$ of new products fail in the market place regardless of the amount of research and test marketing done. In the face of this, the economically rational individual and firm, particularly those with time horizons constrained by other actors, would be entirely reasonable were they to avoid any innovative actions whatsoever. The apparent decline in American innovations is in the view expressed here, entirely to be expected -- innovation, when coldly viewed, is not a good investment (Sheils 1979).

The other side of the coin is that innovations that do pay off, however, bring in sufficiently high gains that more than compensate for the majority of 1osses. It is the "long shot" appeal of some innovations that causes the innovator to run risks beyond the normal limits of good economic judgment. These individuals often have "been captured by an idea", an idea with an imaginative life of its own.

We have described the early market as a risky game. The successful players in this early market, as one might expect, are different from the successful 
players in the mature market. The mature market player, looking at early markets, sees a whole different world than the player who is comfortable in the risky game atmosphere. Classically, the mature market player analyzes the situation as follows in searching for an optimum time to enter the market.

OPTIMAL PARTICIPATION TIME

The element of time plays an important role in any potential player's decision process, and it becomes particularly important when considering participation in the commercialization of a new product. For example, if the decision is made to purchase a new product, when it first appears on the market, a pioneer buyer may be able to maximize his satisfaction. Buyer's satisfaction may include such things as the esteem associated with being the first on the block to own the new product, or the competitive advantage over others in the field by owning a more productive piece of equipment. However, as the pioneer buyer delays his purchase, his satisfaction diminishes since "others on the block" have purchased the new product, or competitors have purchased the product before him.

The reduction in buyer's satisfaction over time must be weighted against the reduction in buyer's risk. Little information is available to the buyer on a product's reliability, performance, etc. When it first appears on the market. Thus, the risk to the buyer of an early purchase is quite high. With time, however, product information is disseminated through the market, reducing the risk.

Both the buyer's risk and satisfaction over time are illustrated in Figure 5.1. The optimal purchase delay time is found where the marginal cost of delay (reduction in satisfaction) is equal to the marginal benefits of delay (reduction in risk). In Figure 5.1 the optimal purchase time for the buyer is $t *$, where the slopes of the risk reduction curve and the satisfaction reduction curves are equal.

At some earlier time, say $t_{1}$, the marginal benefits from delay are greater than the marginal costs of delay. The buyer would thus be wise to postpone his purchase. 


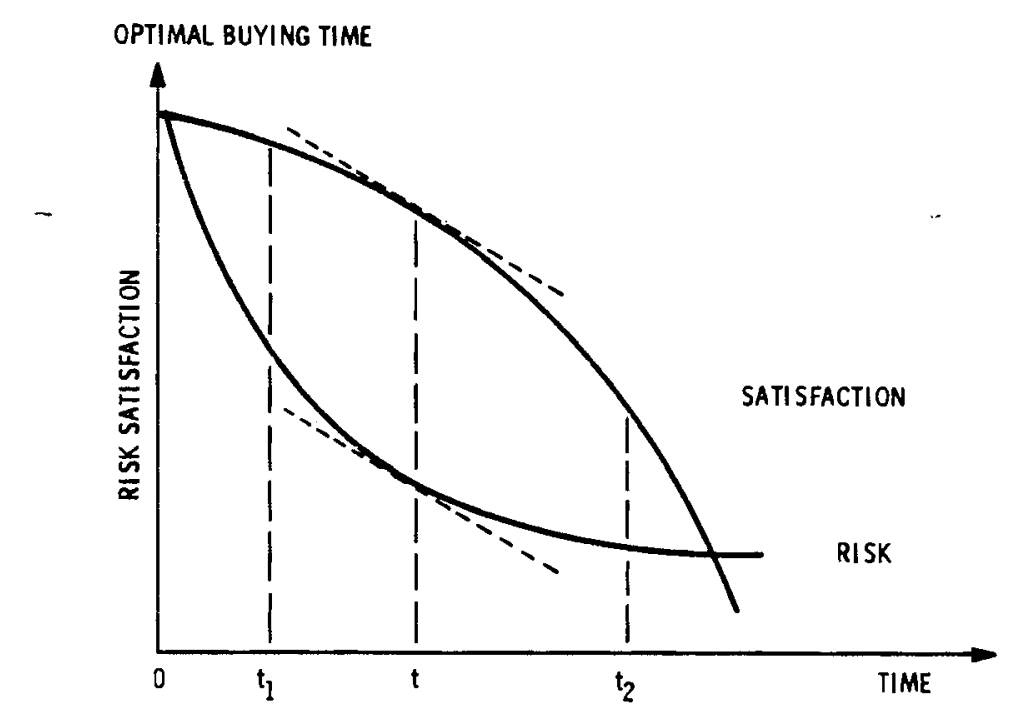

FIGURE 5.1. Optimal Buying Time

At a later time, say $t_{2}$, the marginal costs from delay are greater than the marginal benefits from delay. Even though the buyer has delayed his purchase past the optimum $t^{\star}$, he would be wise to make the purchase immediately since further delay will be even more costly.

The costs and benefits of participation vary from actor to actor. Also, the position and shape of these curves can only be subjectively determined. If they were known, then the optimal delay time for each actor could be determined. If all actors waited in this manner, new products might never emerge.

Fortunately, the early market entrepreneur does not use this kind of language or logic. He typically knows that he is in a risky game but he knows more about the area than the "rest of those idiots" and may even see it as a "sure thing". He may work night and day to make it happen. In such an atmosphere he may appear "compulsive". He may not be overly tactful in dealing with those around him. In any case, he will not likely be a typical "organization man". As a consequence the innovator or pioneer is "different". 


\section{KEY ISSUES}

In reviewing this chapter we have touched on some key issues directly or indirectly. One of these is whether the early market can be skipped altogether. We have touched on this issue by raising the question of risk. It would appear possible to skip the "early market", but risky since the best judgments avai1able in the early market arena are often wrong. Obviously, the farther a poor idea is pushed before its failure is detected, the more costly is the venture. Skipping the early market could be a way of pushing a failure far into commercialization before its fatal flaws are detected.

The other major issue is whether and to what degree the government should be involved in risk ventures. There are those who say that this is precisely the correct role for government. It seems logical that when the risk is manageable the private sector will probably do the job.

However, the nature of government is such that elected, appointed, or tenured individuals may have little to gain and may have much to lose associating with risky early market ventures.

Past attempts at commercializing technological developments by governments have been less than spectacular. Furash (1968) indicates that NASA attempts were disappointing. Cordell and Gilmour (1976) indicate a low rate of utilization of the results from Canadian government research laboratories to the private sector. There have been successes such as hand calculators and nuclear reactors (Perry 1977) and synthetic rubber (Samuelson 1976). But McFeteridge (1977), after analyzing Canadian government R\&D spending, concludes that most government functions in this area are more efficiently performed by private institutions.

Whatever we may feel about government's appropriateness in early market development, we believe that the government is there already and is likely to stay. However, export arrangements are an area where government decision-makers may be uncomfortable. This discomfort may be translated into elaborate topdown systems studies and administrative procedures designed to take the risk out of risk. A sensible amount of computation and administrative procedure can reduce the risk inherent in export ventures. Beyond a modest amount of 
analysis and administration, however, time, money and talent are wasted. The most potentially serious loss is that the brighter minds may move on to less cluttered fields of endeavor rather than fill out forms. 


\subsection{CONCLUSIONS}

- Successful stable industries will flourish best in international trade where all the participants benefit.

- The actors need to perceive the net benefits from participation.

- Emerging technologies and small companies face unique problems in becoming established in international trade.

- Different products and markets need different strategies and trade channels.

- Most of the functions indicated by the actors will be represented in a stable mature business.

- A strategy for commercialization fully energizing innovators may be much more cost effective than "skipping" the early market.

- Encouraging technology push or creating market pul1 may not be the optimum way to accelerate international commercialization. 



\subsection{RECOMMENDED RESEARCH}

We are a need for studies which would:

- Approach the problem of international trade from a holistic point of view.

- Analysis of potential need or demand is not helpful unless additional analyses are made of the concerns and opportunities facing all significant actors.

- Investigate alternative market pathways, transaction costs and benefits for participants in a portfol io of emerging technologies.

- Pathways will vary for different technologies. The principle determining optimum pathways need to be understood.

- Determine preferred pathways and government policies which will encourage commercialization of selected technologies. 



\subsection{REFERENCES}

Campbel1, R.S. and R. L. Watts, Export Potential for Photovoltic Systems. DOE/CS-0078, U.S. Department of Energy, Washington, DC, 1979.

Cohen, K. J. Theory of the Firm. Prentice-Hall, New Jersey, 1975.

Cone, B. W., "An Analysis of Federal Incentives Used to Stimulate Energy Production", PNL-2410 REV., Pacific Northwest Laboratory, Richland, WA, 1978.

Cordell, A. J. and J. Gilmourz, The Role and Function of Government Laboratories and the Transfer of Technology to the Manufacturing Sector. Science Council of Canada Background Study, No. 35, Ottawa: Science Council of Canada, 1976.

Evans, Michael K., Macroeconomic Activity, Harper and Row, New York, 1969.

Furash, Edward E. "The Problem of Technology Transfer", The Study of Policy Formation. Raymond Bauer and Kenneth J. Gergen Eds., Free Press, New York, pp. 281-328, 1968.

Lyon, Peter, "ISAAC Singer and His Wonderful Sewing Machine," American Heritage Magazine. October 1958.

Marubeni Corporation Annual Report, Osaka, Japan, 1978.

McFetridge, D. G. Government Support of Scientific Research and Development: An Economic Analysis. Ontario Economic Council Research Studies, No. 8. Toronto: University of Toronto Press, 1977.

Nelson, R. R. and S. G. Winter, "In Search of Useful Theory of Innovation," Research Policy, $\underline{6}: 36-76,1977$.

Perry, Robert et a1., Development and Commercialization of Light Water Reactors, 1946-1976. Report to the National Science Foundation by the Rand Corporation (R-2180-NSF), Santa Monica, June 1977.

"Report on the Committee on Research Advisory to the U.S. Department of Agriculture." U.S. Department of Agriculture, Washington, D.C., 1972.

Rogers, Everett M., Diffusion of Innovations, The Free Press, New York, 1962.

Samuelson, Paul R. The U.S. Government Synthetic Rubber Program 1941-1955: An Examination in Search of Lessons for Current Energy Technology. Report for Energy Research and Development Administration by Massachusetts Institute of Technology (Working Paper MIT-EL 76-027 WP), 1976.

Servan-Schreiber, J. J., The American Challenge, Antheneum House, Inc., 1967.

Shei1s, Merril, et a1., "Innovation, Has America Lost Its Edge?", Newsweek. June $4,1979$. 
Terleckyj, Nestor E., Research and Development: Its Growth and Composition, National Industry Conference Board, Inc., New York, 1963.

The Unique World of the Sogo Shosha, Marubeni Corporation, 1978. 


\section{DISTRIBUTION}

No. of

Copies

OFFSITE

27

1

1 W. E. Tragert

5214 Pooks Hill Road

Bethesda, Maryland 20014

$1 \quad$ Roger Bezdek

Department of Energy

20 Massachusetts Avenue

Washington, D.C. 20545

1 Norman Lutrefedder

Department of Energy

20 Massachusetts Avenue

Washington, D.C. 20545

1 John Leech

Departinent of Energy

20 Massachusetts Avenue

Washington, D.C. 20545

1 R. C. Spongberg

Solar Energy Research

Institute

1536 Cole Boulevard

Golden, Colorado 80401

1 Joseph Cooper

Department of Energy

20 Massachusetts fivenue

Washington, D.C. 20545

1 Elaine Smith

Department of Energy

20 Massachusetts Avenue

Washington, D.C. 20545

1 Paul Maycock

Department of Energy

600 E Street, N.ll.

Washington, D.C. 20004
No. of

Copies

OFFSITE (Cont'd.)

1 Janet Thomas

U.S. Department of Conmerce Room 4412

ITA/BED/OEMA

Washington, D.C. 20230

John L. Sloop

PRC/EAC

7600 01d Springhouse Road

McLean, Virginia 22102

1 David Doyle

New llark Consulting Group

5214 Pooks Hill Road

Bethesda, Maryland 20014

1 Hoyt M. Weathers

International Solar Energy

Applications

Code FA33

Marshall Space Flight Center

Huntsville, Alabama 35812

$1 \quad$ Andrew Krantz

Department of Energy

600 E Street, N.W.

Washingter:, [.C. 2accia

1 W. Corcoran

Department of Energy

20 Massachusetts Avenue

Washington, D.C. 20545

$?$

Pandit G. Patil

Systems Consultants, Inc.

1054 3lst Street, N.W.

Wasininaton, D.C. 20007

ONSITE

1 DOE Richland Operations Office

H. E. Ransom

R. L. Watts (34)

R. S. Campbel1

S. A. Smith

P. Sommers (10)

C. H. Bloomster

T. L. Willke

Technical Information Files (5)

Publishing Coordination (2) 
